\title{
FANTASMAS DE SI MESMO: UMA LEITURA DEMONÍACA DE JAMES E DE MACHADO
}

\author{
Marcelo Pen Parreira \\ Universidade de São Paulo \\ São Paulo, SP, Brasil
}

\begin{abstract}
Resumo: Este artigo prossegue na discussão sobre o papel do duplo no mundo desencantado da era liberal. Por meio da análise de algumas histórias de Henry James e de Machado de Assis, ele investiga a figuração do sujeito, esvaziado e iludido, assombrado por seu outro eu mutilado - imagem replicada tornada pavorosa pelo horror que o homem moderno comete contra si próprio. As narrativas de Machado, além disso, ao evocar personagens como que possuídos por vestígios de sua "herança bestial" ou por projeções de feitos mundanos (que eles metonimicamente tomam como sua essência integral), desestabilizam ainda mais o conceito de individuação. Nos dois autores, lidar com esse paradoxo também significa conduzir a narrativa a seus momentos negativos ou de falência, quando narrar deixa de ser possível.
\end{abstract}

Palavras-chave: Henry James; duplo; modernidade; falência da narrativa.

\section{Ghosts of one's self: a demoniac reading of James and Machado}

\begin{abstract}
This article continues a previous investigation about the role of the double or the Doppelganger in the disenchanted world of a liberal era. By drawing a comparison between Henry James's and Machado de Assis's narratives, it explores the representation of the deluded modern subject, haunted by his maimed other self, a replicated image rendered hideous by the horror the modern man commits against himself. Moreover Machado's stories evoke characters as if possessed by pieces of their "beastly heritage" or by projections of mundane exploits (which they synecdochically take as their whole essence), further undermining the notion of individuation. In both authors, dealing with this conundrum also means to take the narrative to its own disruptive or negative moments, when narrating seems no longer possible.
\end{abstract}

Keywords: Henry James; Doppelganger; modernity; narrative breakdown.

Os demônios saíram do homem, e entraram nos porcos. E a manada atirou-se monte abaixo para dentro do lago, onde se afogou

Lucas, 8:33.

Perseu precisava de um capacete da invisibilidade para perseguir os monstros. Nós puxamos o capacete mágico a fundo sobre nossos olhos e orelhas, para podermos negar a existência dos monstros.

Marx, prefácio a $O$ capital (1867). 
Cada coisa só é o que ela é tornando-se aquilo que ela não é.

Adorno e Horkheimer, Dialética do esclarecimento.

O duplo já não assombra mais. Foi o que concluímos em um artigo anterior, ao cotejar essa categoria, na formulação proposta por Jean-Pierre Vernant em relação aos gregos antigos, com a representação do duplo na sociedade moderna, vista a partir de algumas narrativas oitocentistas, em especial uma história de Henry James. ${ }^{1}$ Chegamos ao entendimento de que o sentido da concepção nova invertia o do uso arcaico, de modo que, no mundo secularizado, o duplo não está associado apenas a pessoas mortas ou (no caso da tradição africana vodun) à porção do homem correspondente à vida do além, ao pós-morte. O pós-morte é agora lugar nenhum, e o além fica bem aqui. Nesse deslocamento também identificamos o fator social: a era liberal privilegia o invólucro, a capa, o artifício da forma; passa-se a questionar a própria existência ou autonomia do referente objetivo; a sociedade se regozija com o espetáculo, com a cópia, com a publicidade, com as ruínas, os escombros.

Essa conjuntura nos permite explicar, por exemplo, de modo diferente do habitual, uma narrativa mais antiga de James. Em "O último dos Valérios" ("The Last of the Valerii", 1874), um conde apaixona-se pela estátua de Juno, desenterrada em sua villa romana, em meio a uma orgia de associações funestas (a noite, o luar, a ideia da pedra fria). Sim, seu gesto é um último esforço desesperado para abraçar (literalmente?) a tradição de seus antepassados, que agora só pode ser recuperada como ruína ou fragmento, em detrimento do Novo Mundo que ele na realidade desposa (o conde havia se casado com a rica herdeira americana Martha). Cumpre advertir, porém, que, ao entregar-se ao kolossós gelado (duplo da esposa viva), ele também renega a figura de carne e osso, que, no novo estado de coisas, passa a ser fantasia. "Sua Juno é a realidade; eu sou a ficção!", exclama a mulher. ${ }^{2}$ A questão não estaria na adoração de

\footnotetext{
${ }^{1}$ VERNANT, J.-P. Mito \& pensamento entre os gregos. 2. ed. Estudos de psicologia histórica. São Paulo: Paz e Terra, 2002. p. 383 a 398. O artigo, denominado "A magia desencantada: Henry James e o caso de 'Os amigos dos amigos', está no número 94 da Novos Estudos/Cebrap, podendo ser acessado em <http://novosestudos.uol.com.br/v1/contents/view/1483>.

${ }^{2}$ JAMES, Henry. O último dos Valérios. In:

Um peregrino apaixonado e outras histórias. São Paulo: Planeta, 2005. p. 45. O que também explica porque afinal se trata de uma estátua de Juno (a personificação da esposa zelosa), e não de Vênus, como poderíamos esperar (a deusa do amor) ou mesmo
} 
estátuas mortas, mas no enlace de esposas supostamente vivas, ou pelo menos daquilo que elas representam: o conde empobrecido afinal casa com a herdeira por causa do dinheiro. In nuce, o animismo antigo transforma-se em fetichismo hodierno. E quando, por fim, Martha logra devolver Juno ao elemento a que ela pertence de direito, conseguindo que a enterrem de novo, o marido é reconstituído ao mundo das sombras, ou seja, posto que não se torne um "homem inteiramente moderno", está muito mais perto dessa condição. ${ }^{3}$

Mas o que as relações sociais do duplo indicam sobre a representação desse "homem moderno" e sobre a própria narrativa, no último quartel do século XIX e início do XX? Para responder à questão devemos voltar os olhos para outras histórias de James e, agora, também de Machado de Assis. Comecemos com "O espelho: esboço de uma nova teoria da alma humana", de Papeis avulsos (1882), deste último. ${ }^{4}$

Trata-se, como sabemos, da história de Jacobina, que, instado por um grupo de cavalheiros reunidos numa residência de Santa Teresa para discutir "questões de alta transcendência", narra estranhas desventuras ocorridas muitos anos antes. Aos vinte e cinco anos, acabara de ser nomeado "alferes da guarda nacional". Criada na época da Regência com a intenção de assegurar a ordem do Império, a guarda nacional era uma instituição de defesa de origem civil intimamente ligada ao Segundo Reinado (após um período de decadência durante a República Velha, acaba absorvida pelo Exército em 1922). Embora se tratasse de posto modesto, inicial na hierarquia, o cargo de alferes era ainda assim prestigioso o bastante para causar rebuliço não apenas na casa do jovem, mas ainda na pequena vila. A notícia também despertou a inveja dos candidatos preteridos - representantes, como ele, da oligarquia local e detentores de boa renda (de modo que a afirmação de que o moço era "pobre" deve ser levada cum grano salis). Algum tempo depois uma das tias, D. Marcolina, viúva de um capitão, convida-o a passar uma temporada em seu sítio. Uma série de circunstâncias (D. Marcolina sai às

de Diana. (Por razão de espaço opto por dar apenas a versão em português das histórias de James, salvo em casos em que houver alguma divergência semanticamente relevante entre o original e a tradução.)

${ }^{3}$ Idem, p. 50. "Desencantar o mundo é destruir o animismo", afirmam Adorno e Horkheimer no primeiro capítulo de A dialética do esclarecimento, p.18.

${ }^{4}$ ASSIS, J. M. Machado de. Obras completas. v. 2. Rio de Janeiro: Nova Aguilar, 2004. p. 345 a 352. As referências seguintes ao conto dizem respeito a esta edição. 
pressas para visitar a filha, gravemente enferma, e os escravos em seguida fogem) faz com que o rapaz fique sozinho na fazenda.

Achei-me só, sem mais ninguém, entre quatro paredes, diante do terreiro deserto e da roça abandonada. Nenhum fôlego humano. Corri a casa toda, a senzala, tudo, nada, ninguém, um molequinho que fosse. [...] Os mesmos cães foram levados pelos escravos. Nenhum ente humano. Parece-lhe que isto era melhor do que ter morrido? Era pior.

Era a morte em vida, mas um pouco diferente da ideia de "living death" jamesiana. O huis clos do jovem herdeiro não se traduz pelo inferno dos outros: sem os outros, na verdade, ele não consegue constituir-se como pessoa. No grande espelho da época da vinda da corte de D. João VI, mandado pôr no quarto dele pela tia, só distingue um vulto esfumaçado:

[...] porque no fim de oito dias, deu-me na veneta olhar para o espelho, com o fim justamente de achar-me dois. Olhei e recuei. O próprio vidro parecia conjurado com o resto do universo; não me estampou a figura nítida e inteira, mas vaga, esfumaçada, difusa, sombra de sombra. A realidade das leis físicas não permite negar que o espelho reproduziu-me textualmente, com os mesmos contornos e feições; assim devia ter sido. Mas tal não foi a minha sensação.

Enfim, ao moço lembra vestir a farda de alferes e, somente então, o vidro reproduz a imagem integral, "nenhuma linha de menos, nenhum contorno diverso". O caso ilustra a hipótese do personagem sobre as duas almas contidas em toda criatura humana, a exterior e a interior:

Cada criatura humana traz duas almas consigo; uma que olha de dentro para fora, outra que olha de fora para dentro... [...] A alma exterior pode ser um espírito, um fluido, um homem, muitos homens, um objeto, uma operação. Há casos, por exemplo, em que um simples botão de camisa é a alma exterior de uma pessoa; - e assim a polca, o voltarete, um livro, uma máquina, um par de botas, uma cavatina, um tambor etc. Está claro que o ofício dessa segunda alma é transmitir a vida, como a primeira; as duas completam o homem, que é, metafisicamente falando, uma laranja. Quem perde uma das metades, perde naturalmente metade da existência. Shylock, por exemplo. A 
alma exterior daquele judeu eram os seus ducados; perdê-los equivalia a morrer.

A segunda alma pode mudar de natureza e de estado; na infância um cavalinho de pau ou um chocalho; na idade adulta, uma provedoria de irmandade. Uma senhora, bastante frívola, mudaria de alma exterior várias vezes por ano: ópera, concerto, baile do Cassino, rua do Ouvidor, Petrópolis...

Em Machado a ideia das duas almas remonta a Goethe. É o personagem de Aires, em Esaú e Jacó (1904), quem cita o verso do Fausto - "Ai, duas almas no meu seio moram!" - para definir a situação de Flora, dividida entre o amor do republicano Paulo e do monarquista Pedro. O trecho, da cena "Diante da porta da cidade", da primeira parte da tragédia, foi assim vertido por Jenny Klabin Segall:

Vivem-me duas almas, ah! no seio,

Querem trilhar em tudo opostas sendas;

Uma se agarra, com sensual enleio

E órgãos de ferro, ao mundo e à matéria;

A outra, soltando à força o térreo freio,

De nobres manes busca a plaga etérea. ${ }^{5}$

Se Goethe for também neste conto a matriz do autor implícito, vemos que a segunda alma, relacionada pelos exemplos dados em seguida pelo ex-alferes, a objetos externos (mesmo a ideia abstrata de pátria, com a qual Camões morria, ou o poder, a alma exterior de César e de Cromwell, ligam-se a coisas: o país, o governo, que se encontram mais na esfera social ou política do que íntima), alia-se ao "mundo" e à "matéria". No caso do alferes é o invólucro externo, quer seja a farda, quer seja o posto que ela representa, quer seja o estandarte a que a patente primitivamente alude ${ }^{6}$. Já no da senhora frívola (o último dos exemplos mencionados) a aliança se dá com o mundanismo: a rua do Ouvidor, o teatro lírico (a ópera), os bailes (do Cassino), Petrópolis. Machado retomaria dois anos depois essas almas exteriores para designar os

\footnotetext{
${ }^{5}$ GOETHE, Johann Wolfgang von. Fausto: uma tragédia (primeira parte). Tradução de Jenny Klabin Segall. São Paulo: Editora 34, 2007. p. 119.

${ }^{6}$ Originalmente cabia ao alferes ser também o porta-estandarte.
} 
signos de poder e divertimento da elite endinheirada em "Capítulo dos chapéus" (de Histórias sem data, 1884) - acrescentando as corridas do Jockey Club e a sessão da Câmara dos Deputados - todos metonimicamente associados no conto aos chapéus altos, como o do doutor Viçoso. Esse acessório também encarnaria, segundo o "princípio metafísico" apresentado por Conrado, a própria essência ou alma do homem:

\begin{abstract}
Não cuide que quem compra um chapéu exerce uma ação voluntária e livre; a verdade é que obedece a um determinismo obscuro. A ilusão da liberdade existe arraigada nos compradores, e é mantida pelos chapeleiros que, ao verem um freguês ensaiar trinta ou quarenta chapéus, e sair sem comprar nenhum, imaginam que ele está procurando livremente uma combinação elegante. O princípio metafísico é este: - o chapéu é a integração do homem, um prolongamento da cabeça, um complemento decretado ab aterno; ninguém o pode trocar sem mutilação. [...] Pode ser até que nem mesmo o chapéu seja complemento do homem, mas o homem do chapéu... ${ }^{7}$
\end{abstract}

Afora o tom mais zombeteiro empregado pelo marido de Sofia, o que temos em comum? Uma alma exterior que corresponde ao mundanismo, ao mando, ao fetichismo e à frivolidade burgueses - mas o caso apresentado por Jacobina traz um diferencial importante, na situação brasileira: a correspondência também sucede pelo signo do atraso. Afinal, a guarda nacional apontava prenúncio de decadência quando o conto foi publicado. Não só ela decaía, como ainda a escravidão - no sentido de que a Lei do Ventre Livre, promulgada em 1871 pelo gabinete Rio Branco, já marcava o momento histórico em que as feridas do período colonial, juntamente com os sinais da obsolescência da velha ordem, eram trazidas à luz. Os escravos fogem não porque D. Marcolina viajou ou porque o sobrinho era um palerma, mas porque representam aquilo que a propriedade brasileira não podia mais conciliar com os ideais liberais de esclarecimento e de modernidade. Ao fugir, os cativos - que não eram considerados cidadãos, cuja autonomia individual inexiste (podemos concebê-los, pela óptica do oligarca, como "autômatos", ou seja, reduzidos à condição do alferes sem a farda) — ${ }^{8}$

\footnotetext{
${ }^{7}$ ASSIS, J. M. Machado de. Obra completa, cit., p. 403. (Destaques meus.)

${ }^{8}$ Ou ainda "um defunto andando, um sonâmbulo, um boneco mecânico" - sendo a primeira locução a própria tradução literal de Doppelgänger.
} 
deixam também sem contornos individuais o delegado da nossa classe privilegiada. $\mathrm{O}$ que o anima ("era um ente animado", diz ele julgando ter sido restituído à vida, no fim) e o define é a farda, signo do sistema atrasado - sua individualidade estando, portanto, atrelada ao cerceamento da liberdade e da autonomia alheias. Basicamente, como sugere Jacobina, todos esses elementos (pensados liberalmente como indícios de diversão, de festa) são antes fatores que indicam um encarceramento do que uma liberdade. As camadas privilegiadas estariam assim, no sistema atrasado quanto no moderno, presas a uma relação de servidão com os mesmos mecanismos de vantagem criados em seu benefício (a escravidão deveria granjear o ócio ao proprietário, assim como a exploração do trabalho proporcionaria tempo "livre" e distrações agradáveis à burguesia). Como entender a aparente contradição?

Se ao escravo se recusa a autonomia como indivíduo, porque se lhe nega a própria existência de um eu interior (a suposta primeira alma), ${ }^{9}$ desconfia-se de que o alferes, preso como está a uma projeção negativa (a segunda), cuja própria realidade recusa a condição de realidade ao outro que lhe prove verdadeiro, também não chega a constituir-se como indivíduo completamente formado - voltaremos a este ponto. Ambos podem ser considerados autômatos - sendo o autômato, na modernidade industrial, outra das manifestações do duplo. Para dar um só exemplo, lembremos "A pata do macaco" ("The Monkey's Paw", 1902), de W. W. Jacobs, onde a presença maligna (o duplo conjurado) é do pobre operário morto em acidente com uma máquina. O duplo não tem vontade nem individualidade. Carecer-lhe-ia a alma - o esplendor ou radiância da vida ("cháris") -, ${ }^{10}$ consoante naturalmente a perspectiva do dono, do burguês ou do proprietário.

Neste contexto, o duplo é a infâmia a ser enterrada, a culpa bloqueada, o malestar reprimido, a ausência de vontade que volta para clamar o sangue dos infelizes que lhe roubaram a autonomia. ${ }^{11}$ Ele se liga ao mundanismo com tudo o que o fenômeno

\footnotetext{
${ }^{9}$ Os escravos são considerados por Jacobina "espíritos boçais", sendo que a primeira acepção do termo é justamente a do negro recém-trazido ao Brasil e que, portanto, não fala o português. A capacidade de articulação na língua do opressor é a primeira condição para que saia do suposto estado de barbárie que a pretensa civilização lhe impõe pelo sequestro da própria identidade. Sem embargo, mesmo aprendendo a exprimir-se, não consegue livrar-se da pecha - indiretamente aludida do sentido derivado, que acaba suplantando o original, de ignorante, rude, besta.

${ }^{10}$ VERNANT, J.-P. Mito \& pensamento entre os gregos., cit., p. 390.

${ }^{11}$ O narrador e Martha acham gotas de sangue no altar a Juno, em "O último..."
} 
significa - não como causa ou explicação, mas como encarnação das iniquidades e horrores encravados no seio do mundo dito civilizado. Como conjugar a barbárie da escravidão à propriedade colonial? Como harmonizar o fabuloso "poder pecuniário" dos magnatas americanos, assinalada, entre outras, em The American scene e The ivory tower, de James, ${ }^{12}$ com a infâmia de um sistema que suga a vida da maior parte da sociedade, transformando-os em "defuntos andando"? Pois o conceito de independência esclarecida, sabemos, fracassou em 1848 com a carnificina promovida contra as jornadas de junho. E, se o fracasso foi o resultado da falsa fraternidade promovida pela República social de fevereiro, afogada no sangue do proletariado, esta tornaria a rondar "os subsequentes atos da peça como um fantasma". ${ }^{13}$

Trata-se de fantasmas que reaparecem em dois outros contos de James, "A vida privada" ("The private life", 1893) e "A bela esquina" ("The jolly corner", 1908).

No primeiro, o narrador, que desfruta com a "fleur des pois" da sociedade inglesa de uma temporada em um hotel dos Alpes suíços, desconfia de que o dramaturgo Clare (Clarence) Vawdrey seja na realidade duas pessoas: uma persona pública e a figura fantasmagórica do escritor "privado". Em suas palavras: "Um sai, o outro fica em casa. Um é o gênio, o outro o burguês, e só conhecemos o burguês. Ele conversa, ele circula, ele é terrivelmente popular $[\ldots] " .{ }^{14}$

Mas a relação que guarda maior semelhança com a ideia de duplicidade exposta em "O espelho" está na contrapartida de Vawdrey, isto é, em Lord Mellifont. Quando o narrador revela a Blanche sua suspeita sobre o desdobramento de Vawdrey, ela responde que Lord Mellifont não constituiria nem mesmo uma pessoa integral, ou como ela descreve: "Bem, então, meu caro amigo, se Clare Vawdrey é duplicado - e sou obrigada a dizer que acho que quantos mais dele houver, melhor - , sua senhoria aí

${ }^{12}$ A expressão é da primeira obra, embora o desagrado quanto aos avaros anseios e aos efeitos provocados por Mamom encontre-se em ambas.

${ }^{13}$ MARX, Karl. As lutas de classes na França de 1848 a 1850. In: ; ENGELS, F. Obras escolhidas 1. São Paulo: Alfa-Ômega, s/d. p. 273.

${ }^{14}$ JAMES, Henry. A vida privada e outras histórias. São Paulo: Nova Alexandria, 2001. p. 161 a 206. Referências posteriores ao conto são a essa edição. Pelo que James nos conta, a ideia sobre as diferenças entre o escritor público e o alter ego privado lhe ocorreu quando conheceu Robert Browning e estranhou o abismo que havia entre o autor que frequentava a sociedade e o poeta de The ring and the book. (The art of the novel. Organização e introdução de Richard P. Blackmur. Nova York: Charles Scribner's Sons, 1934. p. 249-252; e MATTHIESSEN, F. O.; MURDOCK, K (Orgs.). The notebooks of Henry James. Nova Iorque: Oxford University Press, 1947. p. 109-110). 
tem o distúrbio oposto: ele não é nem inteiro." O aristocrata só existiria como em sua face pública, na companhia de outras pessoas. "Ele era inteiramente público e não tinha uma vida privada correspondente", rumina o narrador. Ou ainda, era "o anfitrião, o patrono, o moderador em qualquer assembleia". Quando deixa de representar o papel principal e sai de cena, quando começa o entr'acte, o ator simplesmente desaparece. Ele é todo "estilo", todo superfície, a máscara lhe domina o rosto; ou melhor, a máscara é o rosto, de modo que, retirando-a, nada se distingue senão o espaço vazio. Como Jacobina desfardado, o lorde não tem autonomia; sem o reconhecimento dado pelos outros às prerrogativas sociais relacionadas com seu status dominante na vida pública inglesa, perde o que supostamente seria sua essência. Sozinho, na completa intimidade, ele não é ninguém.

O conto (talvez pelo foco residir sobretudo no escritor) não explora muito o caráter social, ao contrário de "A bela esquina". Spencer Brydon volta a Nova Iorque após trinta e três anos de ausência. A cidade está transformada. As novidades e estranhezas, "as coisas 'de bazófia', famosas, modernas, monstruosas" lhe agridem os olhos, por toda parte. As mudanças impingidas pelo progresso e pelo dinheiro agora têm na mira sua casa de esquina, onde nascera e vários membros da sua família haviam vivido e morrido. Era do aluguel dela e de outra propriedade, "não tão 'boa'", que ele obtinha o grosso do capital; ou seja, podia "viver na 'Europa', como se habituara, com a renda desses florescentes aluguéis nova-iorquinos". A última ia converter-se num aglomerado de apartamentos. Ele próprio se ocupava da tarefa, provando (pela primeira vez), "pendor para os negócios e um jeito para a construção". Sua desenvoltura é tão grande que a amiga Alice Staverton chega a sugerir que, se ele tivesse "continuado em sua pátria, teria antecipado o inventor dos arranha-céus". ${ }^{15}$

De modo que Brydon cogita o que lhe teria sucedido caso houvesse permanecido na sua cidade natal. Passa a caminhar, tarde da noite, por sua residência de infância. Se ela por ora parece estar a salvo, o mesmo não se pode dizer do "alter ego" que Brydon conscientemente persegue em suas caçadas noturnas. Quando este enfim é apanhado como que em opróbrio, inspira mais compaixão de que medo:

\footnotetext{
15 JAMES, Henry. Até o último fantasma. São Paulo: Companhia das Letras, 1994. p.131 a 170. As referências ulteriores a este conto são a essa edição.
} 
Rígido e cônscio, espectral mas humano, um homem de substância e estrutura igual à sua esperava para medir-se com a sua capacidade de aterrar-se. Só podia ser isso - só isso, até Brydon reconhecer, com o avanço dele, que o que tornava o rosto indistinto eram duas mãos que o cobriam e nas quais, longe de mostrar-se em desafio, o rosto se afundava numa como súplica sombria. [...] pois não podia, nessa outra aflição senão boquiabrir-se ante seu outro eu, como uma prova de que ele, ali de pé para a vida conseguida, desfrutada, triunfante, não podia ser encarada em seu triunfo. Pois não estava, a prova, nas esplêndidas mãos encobridoras, fortes e espalmadas? - tão espalmadas e tão propositais que, a despeito de uma especial veracidade que ultrapassava qualquer outra (o fato de uma dessas mãos ter perdido dois dedos, os quais estavam reduzidos a tocos, como se arrancados por um disparo acidental), o rosto era eficazmente protegido e poupado.

Súbito, a descrição adquire um ímpeto mais aterrorizante quando Brydon enxerga o rosto de "seu outro eu". Naturalmente não o reconhece, pois, mais do que a imagem de si próprio, é a própria sombra que ele enfrenta:

Enquanto ele olhava, as mãos começaram a mover-se, a abrir-se; então, como que num átimo, tombaram de cima do rosto e o deixaram descoberto, à vista. Com um suspiro, o horror saltara para dentro da garganta de Brydon [...]. O rosto, aquele rosto, de Spencer Brydon? [...]. Era desconhecido, inconcebível, medonho, desligado de qualquer possibilidade...! Ele havia sido "traído", gemeu interiormente, tocaiando uma caça como essa: a presença que tinha diante de si era uma presença, o horror que tinha dentro de si era um horror, mas o desperdício de suas noites fora apenas grotesco e o sucesso de sua aventura uma ironia. Uma tal identidade não quadrava a nenhum ponto, tornava monstruosa a sua alternativa. Mil vezes sim, agora que o rosto se acercava mais dele - era o rosto de um estranho. Acercou-se mais, como uma dessas fantásticas imagens expansivas projetadas pela lanterna mágica da infância; pois o estranho, quem quer que pudesse ser, maligno, repelente, espetaculoso, vulgar, avançara em aparente gesto de agressão, e ele se sentiu recuando.

O desenlace é um poço de ambiguidades. Brydon desperta num assento de janela, tendo a seu lado a amiga Alice, que diz ter ido à casa movida por um pressentimento. Afirma tê-lo visto na mesma hora do encontro de Brydon, em sonho. Mas não viu Brydon, e sim seu alter ego. O "estranho sinistro", que Brydon renega 
considerando-o um "horror", "uma fera horrível" ("an awful beast"), era, para ela, merecedor de pena. A diferença estaria em admiti-lo tal como era quando ela o conheceu. Ela o tinha aceitado, como aceita Brydon. Estamos diante da perspectiva de um raro (em James) final feliz.

Podemos dizer, na trilha de Todorov, que o "outro é e não é ele" e que, num mundo em que as verdades parecem ter pouco fundamento, o verbo "ser" perdeu uma de suas funções, quer seja "a de afirmar a existência e a inexistência"16. Há outro ponto, porém. Devemos decidir se a presença duplicada e estranha teria ou não vindo até ele, ou, como mais uma vez sabiamente adverte a amiga: "Você veio a si próprio". ${ }^{17} \mathrm{O}$

\footnotetext{
${ }^{16}$ TODOROV, Tzvetan. Poética da prosa. São Paulo: Martins Fontes, 2003. p. 216 e 217.
}

${ }^{17} \mathrm{O}$ reparo de Alice alude a um movimento crucial da expressão moderna do duplo, evidenciado nas histórias de que estamos tratando: a duplicação ou desdobramento interior do eu em direção ao outro ou ao mundo, seguido de um regresso a si mesmo. Em termos modernos compreende-se que o assunto foi motivo de extensos debates no círculo dos filósofos idealistas alemães, de Fichte a Schlegel, passando por Novalis e Schleiermacher, entre outros. De modo sumário, podemos dizer que o sujeito reflexionante ou Eu Absoluto engendra ou se desdobra um outro eu formal (um si mesmo, que Fichte chama de não-eu e Schlegel, de contra-eu). De todo modo, é por intermédio desse pensamento do pensamento (Benjamin viria a propor a ideia de um terceiro grau da reflexão, "o pensar do pensar do pensar", para definir "a notável ambiguidade dos românticos", p. 63), que o conhecimento do real pode formar-se ("Sentido é sentido dividido", diz Schlegel, em Lyceum, 28), por meio de uma alternância: "Como a essência do espírito é determinar-se a si mesmo e, em eterna alternância, sair de si mesmo para depois retornar [...]", afirma Ludovico na Conversa sobre a poesia (p. 30). Freud propõe uma solução sedutora para a questão do eu cindido e do movimento oscilatório próprio à atividade cognoscente em sua formulação sobre os sistemas consciente e inconsciente, que descreve, em Além do princípio de prazer, como uma espécie de vesícula viva. A grande porção inconsciente, cujos processos são intemporais, ocupa o interior ou núcleo da vesícula, ao passo que o consciente, ligado à nossa concepção abstrata do tempo, engendra-se na camada externa, por meio do contato com os estímulos do exterior. Para defender o organismo de uma provável dissociação, que ocorreria se o contato com as poderosas energias externas fossem diretas, desenvolve-se na parte mais externa da camada consciente um como escudo inorgânico. Sua "morte" salvaria todas as camadas interiores de um destino semelhante. Da mesma maneira, os estímulos externos não se colhem inteiros, mas apenas em fragmentos, capturados como que por pequenos tentáculos da consciência: "Nos organismos altamente desenvolvidos, a camada cortical receptiva da antiga vesícula há muito tempo já se retirou para as profundezas do corpo, embora partes dela tenham sido deixadas sobre a superfície, imediatamente abaixo do escudo geral contra os estímulos. Essas partes são os órgãos dos sentidos [....] É característico deles tratarem apenas com quantidades muito pequenas de estimulação externa e apenas apanharem amostras do mundo externo. Podem ser comparados a tentáculos que estão sempre efetuando avanços experimentais no sentido do mundo externo, e então retirando-se dele. (FREUD, Sigmund. Além do princípio de prazer. São Paulo: Imago, 1998. p. 31 a 36; destaque meu.) Embora minha investigação sobre a versão burguesa, desencantada, do duplo provenha de outras fontes e observações, advirto que um paralelo produtivo pode ser traçado entre as duas abordagens, considerandose, digamos, as categorias do individualismo e da liberdade instauradas a partir da Revolução Francesca. Agradeço as professoras Regina Pontieri e Emília Amaral pelas observações sobre Schlegel e Fichte. Ver SCHLEGEL, F. Conversa sobre a poesia e outros fragmentos. S. Paulo: Iluminuras, 1994; _. A dialética dos fragmentos. S. Paulo: Iluminuras, 1997; SUZUKI, Márcio. O gênio romântico: crítica e história da filosofia em Friedrich Schlegel. S. Paulo: Iluminuras, 1998; e BENJAMIN, Walter. Le concept de critique esthétique dans le Romantisme allemand. Paris: Flammarion, 1986. Sobre a aclimatização do duplo no contexto nacional: PASTA JÚNIOR., J. A. Singularidade do duplo no Brasil. In: A clínica especular na obra de Machado de Assis. Paris: Association Lacanienne Internationale, 2003. 
horror de Brydon estaria em assumir a transformação que efetivamente lhe ocorrera com o passar dos anos, a triste figura a que ele fora reduzido, enquanto, para Alice Staverton, que não se enganava quanto à real identidade da projeção deformada, tal imagem designava menos o estado de uma vida que "poderia ter sido" do que a vida que jamais viria a ser, uma espécie de existência interrompida, como borra no cadinho das fantásticas invenções da era liberal. Ela não tinha dúvida de que a exitosa natureza empreendedora do amigo, se houvesse permanecido nos Estados Unidos, apenas o faria reproduzir a tal "horrenda variedade de lebre arquitetônica", que acossada, apressa-se a entocar-se em uma mina de ouro, na curiosa metáfora do início do conto. ${ }^{18}$ As palavras ditas por ela não saíram de sua mente, assim como as mãos que ocultam (bury) o rosto de seu outro eu refletem a toca em que se mete (burrow) a caça assustada - ou melhor, o potencial de lucro. Não é o outro o horror com que ele se depara, mas o próprio eu esfacelado, regredido por força do sucesso especulativo em cujo encalço ele se lança. $\mathrm{O}$ homem moderno é o ser mutilado. Ele é o fantasma de si mesmo, o infinito que se equilibra ao pé do abismo dos sonhos abortados em prol da geração dos ganhos futuros.

Nesse e noutros sentidos, a amiga não deixa de constituir o duplo de Brydon. Alice Staverton é a proprietária que permanece fiel à imagem da antiga Nova Iorque, opondo-se assim ao proprietário mundano e "reformista" Spencer Brydon. A coincidência e o caráter diferencial contíguo das iniciais (A.S. $\leftarrow \rightarrow$ S.B.) não parece fortuita, como não é fortuita a escolha no nome Alice para a co-protagonista, o mesmo da irmã de James, falecida precocemente, que simboliza para ele o espírito da firmeza e coerência de caráter, e cujo talento se manteve soterrado sob as conveniências e abusos, à sombra da vertiginosa (como um arranha-céu?) obra do irmão cosmopolita. ${ }^{19}$

O alter ego de Brydon reproduz o melancólico destino de Clement Searle na novela "Um peregrino apaixonado" ("A passionate pilgrim", 1875), emblema do fracasso, um contraste não apenas com fulgurante progresso de seu país natal, como também com a condição atual do herdeiro e investidor, que vive confortavelmente de

\footnotetext{
${ }^{18}$ No original (JAMES, Henry. The beast in the jungle and other stories. Nova Iorque: Dover Publications, 1993. p. 73-101): "[...] some new variety of awful architectural hare [...] burrowed in a gold-mine". Convertendo-se depois, como vimos, em "awful beast".

${ }^{19}$ Há outros elos com a biografia de James. Por exemplo, o autor sofreu um "obscure hurt" ou "injury" pouco antes da Guerra de Secessão, que ao mesmo tempo oculta e usa (para fugir ao alistamento). Esse ferimento o liga ao pai, que perdera uma perna na adolescência. Como os dois, o outro eu de Brydon, sua cópia manquée, é um homem diminuído em razão da sua mutilação.
} 
ganho de capital e (re)encontra sua veia empreendedora. Se sua fortuna é porventura mensurável, o terror que ele configura escapa ao cálculo, e é por isso tão mais aterrorizante ("Muita gente vivera no terror das aparições, mas quem jamais virara assim a mesa e se tornara ele próprio, um grandíssimo terror" - no original: "an incalculable terror"). Não apenas ele possui a "calma segurança do proprietário" ("the assurance of calm proprietorship"), como confessa que, nos anos passados na Europa, adquiriu os hábitos da criatura mundana, levando "uma vida egoisticamente frívola e escandalosa" (destaques meus), os quais retoma na volta ao lar:

Ele circulava socialmente; entretinha, renovava, descuidadosa e aprazivelmente, antigas relações sociais [...] Alcançara mediano e apagado êxito mundano - e com gente que não fazia verdadeiramente ideia de quem ele fosse. Era bastante superficial o murmúrio da acolhida que lhe davam, o espoucar de rolhas em seu louvor - de igual modo, seus gestos de resposta eram as sombras extravagantes, enfáticas na mesma proporção do pouco que representavam, de alguma brincadeira de ombres chinoises. ${ }^{20}$

Se a vida mundana assemelha-se às ombres chinoises, a casa representa "a outra vida, a verdadeira, a expectante" ("the other, the real, the waiting life"). Em poucos momentos anuncia-se tão nítida quanto nesta passagem a ideia da desilusão burguesa de que falam Adorno e Horkheimer na Dialética do esclarecimento, a renúncia aos sonhos que o indivíduo astucioso ou bem-sucedido deve empreender para tornar-se sujeito da ordem racional. Seu "outro mundo místico", composto de "todas as velhas frustras renegadas possibilidades" ("of all the old baffled forsworn possibilities"), soa-lhe mais real do que insubstancialidade, a incalculabilidade e a artificialidade da vida moderna (tomada por sombras chinesas, ou, na descrição de Brydon sobre o caráter assustador do seu outro eu, por lanterna mágica); ${ }^{21}$ ele só pode ser conjurado através do artifício do "estilo" ou da "Forma" - cuja maiúscula, usada no conto, confere ar de onipresença - destituída de conteúdo. Somente se acessa o recalcado dessa vida

\footnotetext{
${ }^{20}$ Introduzi uma pequena alteração na tradução, para eliminar a ambiguidade, que não há no original: em vez de "ideia do que fosse", proponho "ideia de quem ele fosse". (Destaques meus.)

${ }^{21}$ A lanterna mágica, associada à infância, leva-nos a refletir sobre o caráter pouco inocente de tais brincadeiras: o gênio mecânico a tomar parte da "formação" dos lares burgueses e da classe média atraída aos espetáculos públicos. Vale lembrar ainda que a associação entre as sombras chinesas e a lanterna mágica popularizou-se nas fantasmagorias a partir do fim do século XVIII.
} 
verdadeira, à espreita, como "vida fantasmática" ("ghostly life"). Não surpreende que o proprietário logre-a alcançar por meio da "figure" por trás de todas as "figures in the carpet" das histórias jamesianas, os algarismos da transação financeira, ${ }^{22}$ a um só tempo palpável e abstrata, corriqueira e assombrada. A vida em potência se converterá em espécie, embora o susto possa matar. Assim, podemos entender melhor o paradoxo de Searle e do alter ego de Brydon - exemplos de fracasso e vergonha em meio a condições prósperas. Menos do que exceções à regra, eles ilustram as aspirações (culturais, artísticas, sociais) que o homem exitoso deve renegar para viver na nova ordem. E carregam no corpo as marcas dessa renúncia.

Voltando a "O espelho", sabemos que o confronto do alferes não é fatal, mas o moço poderia ter enlouquecido ou desaparecido se o espelho não lhe devolvesse o reflexo (seu duplo). Não obstante, o espelho reclama a casca, o que o personagem é aos olhos dos outros, sua farda, sua posição social (de "senhor alferes"). Enquanto Brydon persegue a individualidade perdida, recalcada, mutilada, tornada pavorosa pelos horrores que o homem moderno comete contra si próprio, o alferes é obrigado a vestir aquilo que o espelho (o olhar alheio) exige dele: o ornamento, o acessório. E se o detalhe configura a substância, também não devemos esquecer o que representa o pormenor: o prestígio da distinção civil para a proteção da oligarquia, adquirindo não por acaso forma diante daquela relíquia da metrópole: o espelho vindo com a corte de D. João (isto é, de fora para dentro.)

O reforço do dado colonial não parece fortuito, com seus ouropéis e delfins esculpidos e enfeites de madrepérola. A aliança está clara, como está claro o elemento que se evade: não a sombra daquilo que poderia ter sido ou que jamais seria, mas o sustentáculo da barbárie proprietista: a escravidão. Logo no início Jacobina, considerado (como Aires) homem avesso à controvérsia, não somente evoca a perfeição celeste de serafins e querubins que nunca controvertem, como ainda alega que a discussão nada mais seria do que a forma polida da herança bestial inerente ao homem.

\footnotetext{
${ }^{22}$ Sua visão se manifesta tão clara para ele quanto os "algarismos de um cheque a ser pago em dinheiro" ("the figure on a cheque presented in demand for cash"). Em The ivory tower (1917, póstumo), a descrição da aridez mental do bilionário Abel Gaw chama a atenção para o fato de que "if he hadn't thought in figures how could he possibly have thought at all" (Como mais é que ele iria pensar se não fosse em termos numéricos). JAMES, Henry. The ivory tower. Nova Iorque: New York Review Books, 2004. p. 7. (Destaque meu.)
} 
O desenrolar do conto naturalmente transporta esse dado generalista (e determinista) para nossa condição histórica particular. Afinal, quem precisa "batalhar" não são os representantes da oligarquia, mas os excluídos da esfera do mando: a classe dos trabalhadores livres e os escravos - estes últimos, aliás, a verdadeira "herança bestial", que ele, na condição de herdeiro e futuro proprietário, historicamente recebe, politicamente recalca e socialmente reinstaura. Os delfins (a cujos fumos de nobreza ele certamente aspira) são, nesse sentido, em seu artificialismo deslocado, a própria expressão do dado insubstancial, fazendo a ponte entre a impostura moderna e o idealismo vazio e essencialmente boçal ${ }^{23}$ que está no fulcro de seus anseios.

Vejamos a seguir alguns esquemas de duplos, a partir dos principais contos examinados: ${ }^{24}$

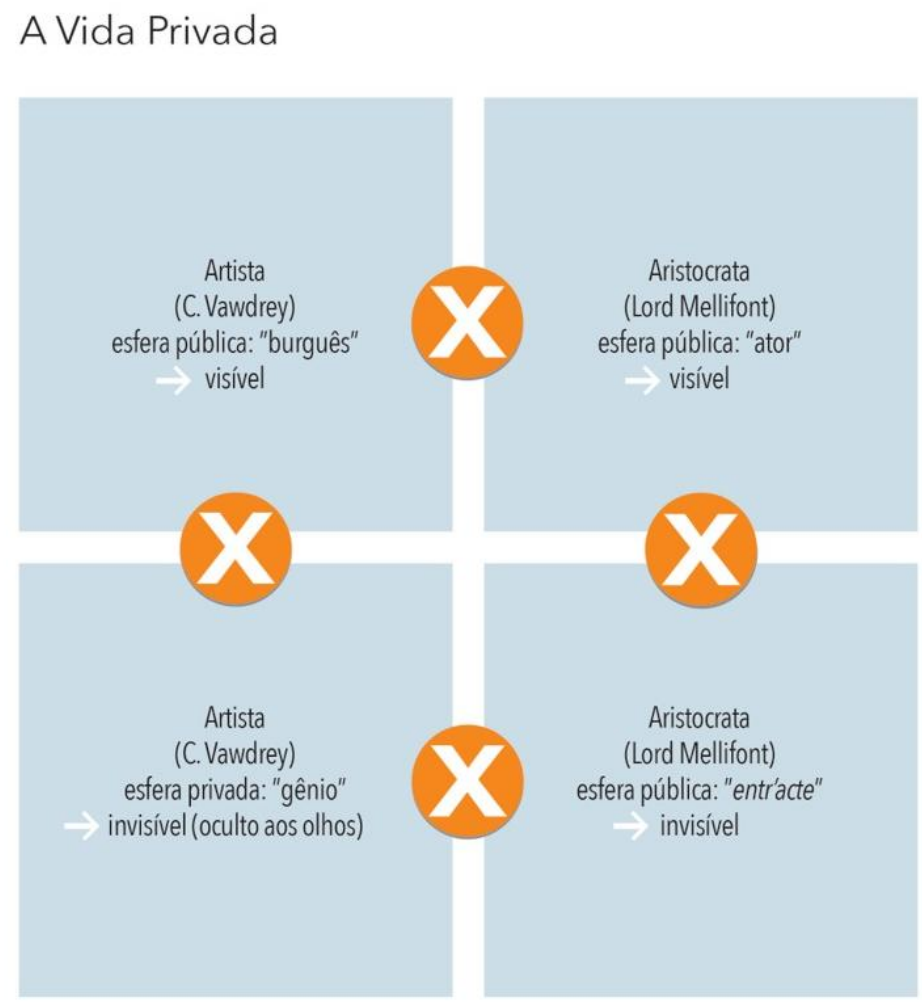

\footnotetext{
${ }^{23}$ Se ao escravo é dirigida a injúria, marca da violência que define sua origem histórica e seu (não) lugar social, a boçalidade do senhor é tanto mais efetiva no sentido de que sua formação não é propriamente imposta, mas "vendida" à maneira de gato por lebre: ele acredita na gênese fidalga, supondo eximir-se de seu legado realmente bestial: como ao escravo, a linguagem do outro (a metrópole, a fidalguia) lhe é vedada, mas, ao contrário do primeiro, que (re)conhece a sua sina, ele prefere comprazer-se com a quimera

${ }^{24}$ Agradeço a Luiz Antonio Morikio a arte dos diagramas.
} 


\section{A Bela Esquina}

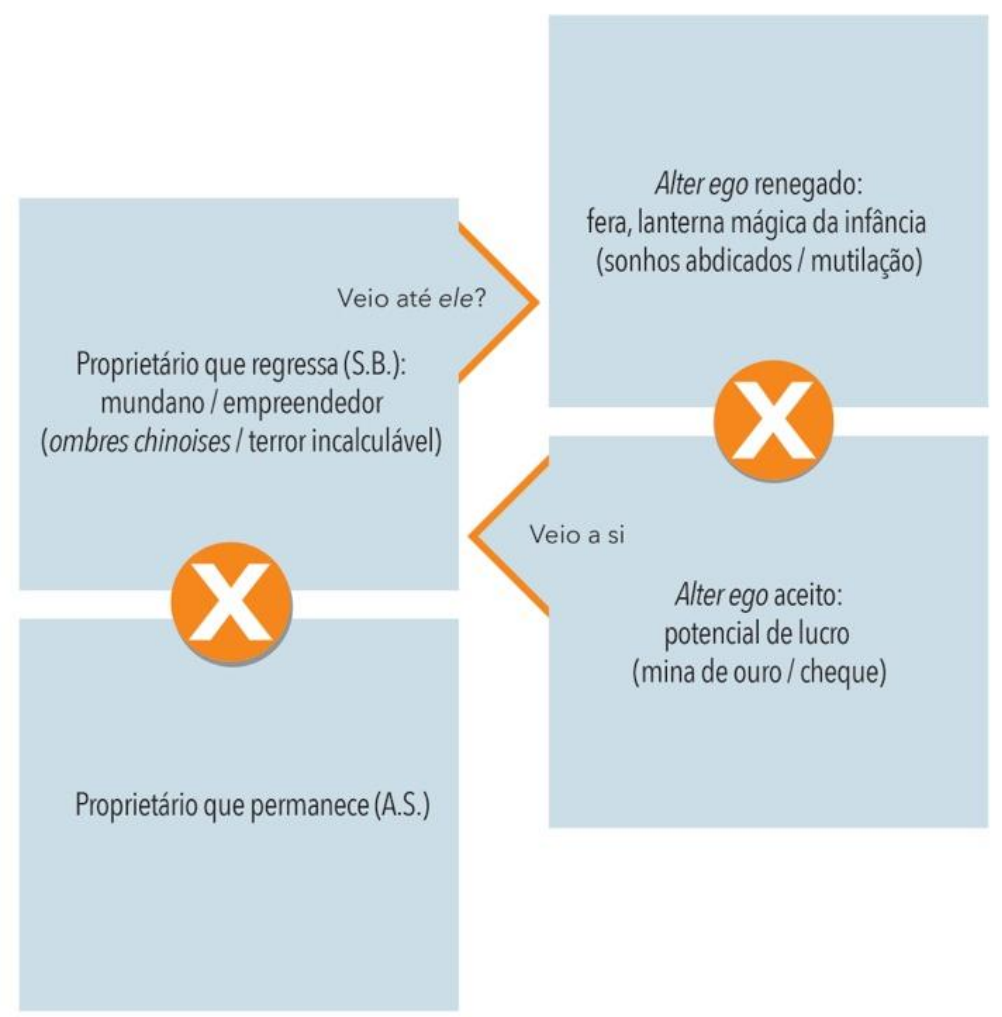

\section{O espelho}

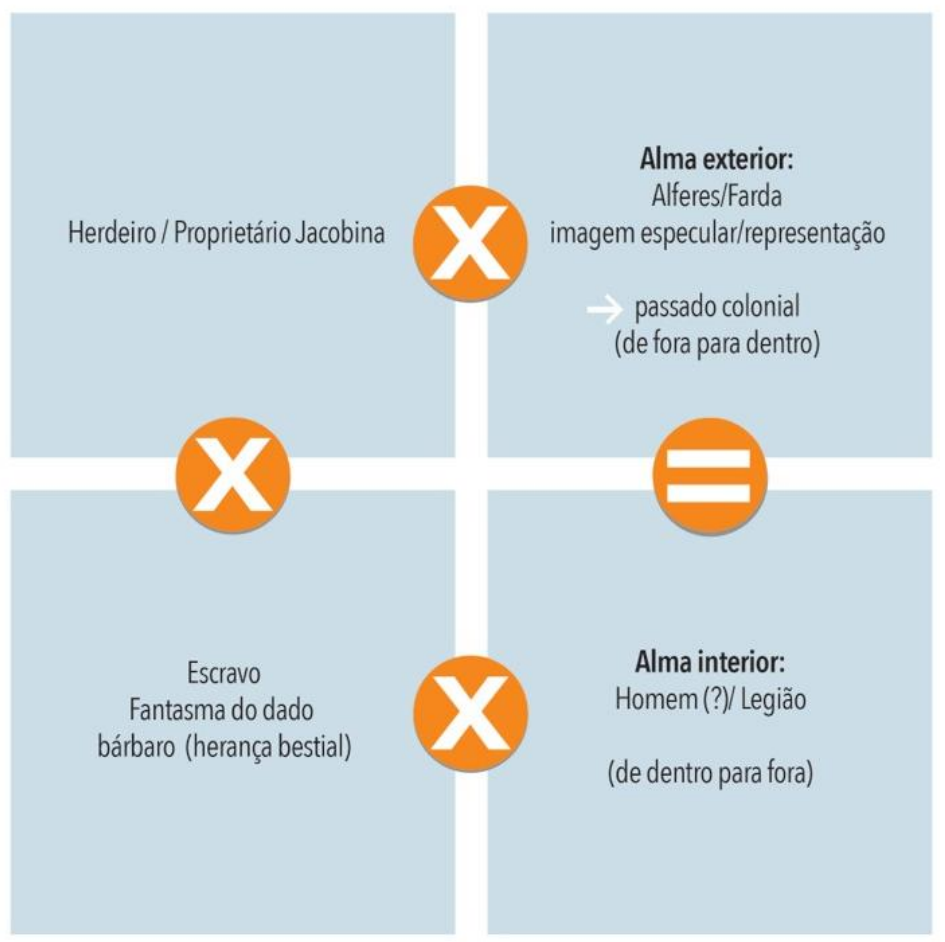


Vamos nos deter, nestas observações finais, apenas no conto de Machado, que parece elucidar um aspecto interessante da questão que vimos tratando. Em princípio seguimos a irônica advertência de que a alma exterior e a alma interior são as duas partes que completam o homem, como uma laranja, neste sentido diferindo da situação de Brydon e de Vawdrey, que se materializam em entidades distintas. No entanto, não devemos esquecer que o Jacobina narrador não coincide exatamente com o Jacobina como ator da diegese, o jovem alferes recém-empossado no cargo - sendo esta uma das diversas trocas da alma exterior. O duplo real e histórico a ser contraposto (ou seja, o negativo, o excluído) a ambos é o escravo; sua função no conto como desencadeador da crise também lhe confere profundezas insuspeitadas à primeira vista, respondendo à boçalidade que o dominador lhe impõe com a boçalidade que o último é incapaz de enxergar em si mesmo, cego que se encontra às diversas instâncias de desajuste histórico, social e existencial.

Contudo, a que espécie de homem devemos associar a alma interior? O texto não nos ajuda muito, conjugando apenas o termo "homem" ("O alferes eliminou o homem") à humanidade ou vestígio de humanidade. Entretanto, como Shylock sem seus ducados, este homem não é ninguém; o alferes desaparece sem a farda. Os conceitos sofrem deslizamentos constantes em Machado. A alma interior parece nunca de fato ter vida sem a alma exterior - é essa que realmente anima a primeira -, sem ela, a primeira nem sequer é percebida, reduzindo-se à inexistência que talvez seja sua real natureza. A alma interior ademais vivifica no sono, quando a alma exterior em tese se tornaria desnecessária. Porém, tudo o que o sonho do alferes faz é repetir a antiga experiência estéril da vigília, apresentando-o fardado em meio aos seus. Em termos freudianos, os estímulos externos de tal modo petrificaram os instintos do eu, que este só obtém prazer morrendo. Pois, no fundo, percebe-se a emergência do instinto de morte retrógrado, cuja compulsão à repetição dá ar de força demoníaca de que fala Freud no artigo supracitado. $^{25}$

Convém notar que a senhora frívola, sempre a trocar de alma exterior (em essência, sempre a mesma), é chamada justamente de Legião, parenta do diabo.

\footnotetext{
${ }^{25}$ FREUD, Sigmund. Além do princípio do prazer, cit., p. 45.
} 
Jacobina, em seguida, confessa ter "experimentado dessas trocas". Sabemos que além dos múltiplos demônios que se apossaram do homem que andava sem roupa pelos sepulcros, segundo os Evangelhos de Marcos e de Lucas, Legião era o termo que designava a unidade principal do exército romano - ela presidia sobre os judeus, assim como o corpo da guarda nacional mantinha sob controle os subalternos do Império brasileiro. Se Jesus expulsa os demônios do interior do andarilho nu, o alferes veste a farda legionária, signo externo do pacto inferno-imperial. Mais: o relato, através do qual Jacobina obtém atenção, reforça o poder e impõe seu argumento, não exorciza pela palavra nenhum demônio interior - até porque no nosso entender não há nada interno a pôr para fora -, mas cobra da plateia curiosa de iguais o seu quinhão pela impostura.

A referência à dor que a suposta alma interior sente com o tique-taque do relógio de nada ajuda a dar-lhe sentido: ao negar o tempo cronológico (a história), a eternidade (atemporalidade) roda no vazio do nunca mais, para sempre. Os querubins despencam no abismo. De modo que a constituição do sujeito fica comprometida por uma sequência de negações e repressões, que ganha contornos mais precisos justamente quando se liga à herança bestial, ao dado ignominioso, vergonhoso (que não pode ser visto) e que transforma dominador (pela inconsciência) e dominado (à revelia) em autômatos, defuntos andando, seres sem vida verdadeira. Ou ainda, na Legião que configura a compulsão marginal (o vagamundo dos sepulcros) e depois anima os porcos (homens regredidos?), que, como "classe", precipitam-se na dissolução.

Queremos propor assim uma leitura como que demoníaca à teoria anunciada pelo conto, dizendo que, com efeito, a alma interior não existe, ou melhor, existe, mas na condição de própria alma exterior. É a alma exterior, múltipla, fragmentada, todavia mais real em sua estrutura assombrada do que a forma informe do indivíduo mutilado, enredado em sua ilusão de autossuficiência, que engendra o personagem como homem. Assim, formam-no não só o passado colonial, mas ainda os traços de modernidade desajustados, como demônios que a narrativa-confissão não logra expulsar (de dentro para fora). Não é o duplo que pode ou não existir, como no conto de James, mas, de 
modo ainda mais flagrante, o próprio $e u .{ }^{26}$ Jacobina pode ou não ser considerado o quinto personagem e, no fim, some diante dos demais.

Se em princípio, entretanto, o conto de Machado parece apontar numa direção contrária daquela expressa pelas histórias de James, não podemos esquecer que, enquanto o mundanismo encarna o terror e o caráter fugaz e impalpável, o alferes tenta livrar-se da inevitável perda da individualidade vestindo o elemento acessório, concreto, muito embora este também constitua uma representação (para os outros, para si mesmo), corporificada, também não por acaso, diante do espelho: é, em suma, apenas uma imagem, oca, ilusória. A ficção, por sua vez, ainda que revele a barbárie da alma exterior, ombre chinoise, não alcança ultrapassar a moldura e a superfície que reafirma as prerrogativas do elemento externo, metropolitano, dominante.

O caráter de representação não escapa, portanto, da responsabilidade pela impostura que se instala no palco das relações sociais - afinal, ela mesma está no banco dos réus (desde 1848) por causa justamente da falsidade do procedimento especular ou superficial na apreensão da matéria e ainda porque seus véus toldariam a verdadeira cisão do homem - social (capital $\times$ trabalho), histórica (civilização $\times$ barbárie), psicológica (inconsciente $\times$ consciente) e existencial (vida vicária ou desperdiçada $\times$ vida verdadeira).

Ao enveredar por essa trilha, cada narrativa, a seu modo - diante da inquietante lógica de um mundo racionalmente ordenado, em cujas fissuras distinguem-se suas contradições, o dado bárbaro, o reprimido -, chega também a um ponto de falência representacional, quando narrar deixa de ser possível: o "exorcismo" às avessas do alferes, as horas que se seguem ao colapso de Brydon, a desintegração de Lord Mellifont. Nos três casos o homem decompõe-se quando despossuído do próprio privilégio de possuir, enquanto os parcos indícios de tal condição (desfalecimento, desaparecimento) precedem a retirada ora prudente, ora irônica, do narrador. A dúvida sobre a realidade de tais situações é transferida ao leitor, junto com os sinais do processo que leva a narração às portas da negatividade narrativa. A narração, em suma,

\footnotetext{
26 "O eu é tão incerto quanto o ser", diz Todorov sobre "A bela esquina". TODOROV Tzvetan. Poética da prosa, cit., p. 218.
} 
enfrenta seus próprios demônios, convocados pela incômoda suspeita de que o mundo a está obrigando a calar.

\section{Referências:}

ADORNO, T. W. \& HORKHEIMER, M. O conceito de esclarecimento. In: A dialética do esclarecimento. Rio de Janeiro: Zahar, 2006.

ARMSTRONG, Nancy. The fiction of bourgeois morality and the paradox of individualism. In: MORETTI, Franco. The novel - volume 2: forms and themes. Princeton: Princeton University Press, 2006.

ASSIS, J. M. Machado de. O espelho; Capítulo dos chapéus. In: . Obras completas. v. 2. Rio de Janeiro: Nova Aguilar, 2004.

BENJAMIN, Walter. Le concept de critique esthétique dans le Romantisme allemand. Paris: Flammarion, 1986.

FREUD, Sigmund. Além do princípio de prazer. São Paulo: Imago, 1998.

GOETHE, Johann Wolfgang von. Fausto: uma tragédia (primeira parte). Tradução de Jenny Klabin Segall. São Paulo: Editora 34, 2007.

JAMES, Henry. O último dos Valérios. In: Um peregrino apaixonado e outras histórias. São Paulo: Planeta, 2005.

A vida privada. In: A vida privada e outras histórias. Tradução e apresentação de Onédia Célia Pereira de Queiroz. São Paulo: Nova Alexandria, 2001.

A bela esquina. In: Até o último fantasma. Seleção, tradução e posfácio de José Paulo Paes. São Paulo: Companhia das Letras, 1994.

The Jolly Corner. In: . The beast in the jungle and other stories. Nova Iorque: Dover Publications, 1993.

The art of the novel. Organização e introdução de Richard P. Blackmur. Nova Iorque: Charles Scribner's Sons, 1934.

MARX, Karl. As lutas de classes na França de 1848 a 1850. In: MARX, K.; ENGELS, F. Obras escolhidas 1. São Paulo: Alfa-Ômega, s/d.

MATTHIESSEN, F. O.; MURDOCK, K (Org.). The notebooks of Henry James. Nova Iorque: Oxford University Press, 1947.

PASTA JÚNIOR, J. A. Singularidade do duplo no Brasil. In: A clínica especular na obra de Machado de Assis. Paris: Association Lacanienne Internationale, 2003.

SCHLEGEL, F. Conversa sobre a poesia e outros fragmentos. Tradução, prefácio e notas de Victor-Pierre Stirnimann. São Paulo: Iluminuras, 1994. 
A dialética dos fragmentos. Tradução, apresentação e notas de Márcio Suzuki. São Paulo: Iluminuras, 1997.

SUZUKI, Márcio. O gênio romântico: crítica e história da filosofia em Friedrich Schlegel. São Paulo: Iluminuras, 1998.

TODOROV, Tzvetan. O segredo da narrativa. In: . Poética da prosa. São Paulo: Martins Fontes, 2003.

VERNANT, J.-P., Mito \& pensamento entre os gregos. 2. ed. Estudos de psicologia histórica. São Paulo: Paz e Terra, 2002.

Marcelo Pen Parreira é professor do Departamento de Teoria Literária e Literatura Comparada da Faculdade de Filosofia, Letras e Ciências Humanas da Universidade de São Paulo. É autor de Realidade possível: dilemas da ficção em Henry James e Machado de Assis (Ateliê, 2012) e tradutor de, entre outros, Os embaixadores (Cosac Naify, 2010) e A arte da ficção: antologia de prefácios (Globo, 2003), de Henry James. E-mail: <marcelopp@usp.br>.

Aprovado: 04.09.2013

Recebido: 20.11.2013 